\title{
Settler Governmentality and Racializing Surveillance in Canada's North-West
}

\author{
JEFFREY MONAGHAN
}

\begin{abstract}
Examining archival materials from the mid-1880s, this article details practices of racializing surveillance carried out in the North-West. I focus on the reports from an undercover agent from the Department of Indian Affairs named Peter Ballendine. Contributing to literature on Foucauldian interpretations of race and racialization, Ballendine's correspondence reveals a campaign of covert surveillance and infiltration that imbued indigenous leaders with characteristics of dangerousness, abnormality, and deviance, translating indigenous demands for rights and dignity into threats to security of the budding Canadian settler state. Stressing that settler colonialism follows a structured logic of elimination, I use the concept of settler governmentality to stress that the rationalities of colonial governance in the North-West approached indigeneity - especially expressions of counterconduct - as threats to the health, prosperity, and legitimacy of settler society.
\end{abstract}

Keywords: Foucault; race; surveillance; governmentality; settler colonialism; security.

Résumé. Dans cet article, les pratiques de surveillance racialisées dans le nordouest du Canada durant les années mi-1880 sont examinées. En particulier, l'article analyse les rapports qui se retrouvent dans des archives d'un agent couvert, Peter Ballendine, qui été employé par le Département des affaires indiens. Ces rapports incluent des lettres qui décrivent une campagne d'infiltration et de surveillance qui a documentée des caractéristique dites indiennes fixées sure des notions de dangerosités, d'anormalités, et déviances. Les fixations de dangerosités sont particulièrement concentré sur les chefs du mouvement pan-indigène. Contribuant à la littérature Foucauldien sur la race et les processus de racialisation, l'article emploi le concept de « settler governmentality » pour examiner les rationalités de gouvernance colonial dans le nord-ouest pour démontrer comment les pratiques policières ont réagit aux populations indigènes comme des menaces à la santé, prospérité, et légitimité du régime colonial.

Mots clés: Foucault; race, surveillance; gouvernementalité; colonialisme; sécurité. 


\section{INTRODUCTION}

2) ace and racialization are central components to colonial surveillance $\int$ practices. Scholars have noted how colonial authorities develop systems of identification, categorization, and enumeration that become surveillant infrastructures for the biopolitical management of colonial populations (Cohn 1996; Hacking 1982; Smith 1985). As techniques of colonial governance, surveillance practices not only aim to manage indigenous populations, but tend to produce racial subjectivities according to prefabricated typologies and normative demarcations held by settler societies. Scholarship on Orientalism has detailed how race was constructed through the colonial imagination of occidental gaze, and many of these fantasies and manifestations of colonial power were central to the construction of indigeneity in North America (Francis 1992; Lawrence 2004). As Keith Smith (2009:4) has noted, colonial governance and the expansion of liberalism (particularly through the Canadian prairies) was premised on "... ways of knowing Indigenous peoples and their territories, [and] was facilitated and fashioned by means of surveillance."

Contributing to literature that develops a Foucauldian understanding of race, racialization, and settler colonialism, I demonstrate how surveillance was an important component in the efforts of the Canadian government to eliminate indigenous opposition to settler colonial expansion in the North-West. Examining correspondence materials that immediately predate the 1885 Rebellion, I explore how surveillance practices contributed to processes of racialization that underwrote the radical transformations forced on indigenous people of the North-West. Simone Browne (2012:73) uses the term "racializing surveillance" to describe how things get ordered racially to uphold colonial Othering practices that seek "to structure social relations and institutions in ways that privilege Whiteness." In the context of the North-West, surveillance was necessary for identifying indigenous peoples and sorting them based on their adoption of, or resistance to, practices of European liberalism imposed by the Canadian settler state. As settler colonialism was seen as the civilized progression of European reason, colonial surveillance practices necessitated a vigilant gaze towards traces of indigeneity that marked deviant behaviour from, or dangerous threats towards, the expansion of settler governance.

To illustrate how racializing surveillance was integral to the radical transformations in the North-West circa 1884, I examine correspondence records from the Department of Indian Affairs (DIA) that focus on the movements of indigenous leaders — such as Big Bear, Poundmaker, Little Pine, and Little Poplar - identified by the Canadian government as dangerous. In most circumstances, they were leaders who objected to the Canadian government's treatment of indigenous peoples and, in particular, the nonfulfilment of Treaty responsibilities (Tobias 1983). These individuals were involved in building a pan-indigenous movement that opposed many facets of settler Canadian expansionism (Stonechild and Waiser 1997). While there were a number of techniques that colonial authorities employed to gather information on these individuals, I focus on one in particular: the reports from an undercover operative in the employ of DIA named Peter Ballendine.

Ballendine's correspondence with the upper echelons of the Canadian government reveals an intimate campaign of surveillance and infiltration. For this article, I analyze Ballendine's surveillance practices as contribution to the conceptualization of settler governmentality (Crosby and Monaghan 2012). Through Ballendine's correspondence, I trace how colonial authorities translated ruminations and reports from the NorthWest frontier according to racially constructed continua of conduct and threat. By relating Ballendine's surveillance practices against theoretical frameworks provided by Foucauldian scholars of racialization (Mawani 2009; McWhorter 2009; Stoler 1995; Su Rasmussen 2011) and scholarship from settler colonial studies, I underline that settler governmentality follows a "logic of elimination" (Wolfe 2006) where the settler majority views indigeneity as a threat to the project of acquiring (settling) land and establishing a post-colonial state (Crosby and Monaghan 2012; see also Veracini 2010). Focusing on the North-West, I explore how Ballendine's campaign of surveillance assisted in classifying specific actors according to a racial continuum of white normative society, where conduct associated with the white liberal norm is rewarded, and conduct associated with indigeneity is viewed as a mark of abnormality, uncertainty, and dangerousness. Since Ballendine's correspondence records were directed foremost at reporting on the activities of the leaders of the pan-indigenous movement, he produced unique racializing surveillance that contributed to the categorization of indigenous leaders as exceptional sources of threat and rationalized the need to immediately neutralize their efforts.

This article has four parts. First, I detail Foucault's fragmentary comments on race and colonialism. Sketching out Foucault's works on race, I engage with other scholars who have built on elements of his work with a particular focus on colonial governmentality studies and the centrality of racializing surveillance. The second section offers a brief historical overview of Canadian expansion in the North-West and relates this history to literature on colonial governance and notions of dangerousness. Subsequently, I detail the archival materials related to Peter Ballendine's covert surveillance campaign. Finally, I conclude with a discussion that 
relates these archival materials to practices of settler governmentality and racializing surveillance. Through the examination of archival materials, I argue that racializing surveillance is an integral aspect in the reification of distinctions between liberal settler society and illiberal indigenous peoples. Analyzing Ballendine's reports from the North-West, I conclude with a discussion of how rationalities of settler governmentality target expressions of indigeneity as threats to the health, prosperity, and legitimacy of settler society that must be eliminated.

\section{Race, Surveillance, and Settler Governmentality}

Foucault has been criticized for not adequately addressing issues of race and colonialism (Mawani 2009; Mbembé 2003; Stoler 1995). Nonetheless, many of his critics have expanded on Foucault's fragmentary comments on the place of race and colonialism within biopower (Kelly 2004; McWhorter 2009; Su Rasmussen 2011; Stoler 1995). While many Foucauldian studies on biopower focus on a movement away from practices of sovereign power, Foucault's treatment of race in colonial circumstances demonstrates how sovereign power and biopower were "conjoined and braided as opposed to distinct" (Mawani 2009:18; see also Kelly 2004). Stoler (1995) shows that biopolitics retains key elements of sovereign power, but as a new configuration centred on race. Race becomes a set of subdivisions in which certain races are classified as "good," fit, and superior, (Stoler 1995:84), while subraces that are considered "excess" or classified as dangerous to the aggregate population can be contained and/or eliminated.

McWhorter (2009) has demonstrated that the modern racism traced by Foucault is about forms of abnormality that are coded as race. Deviating from biomedical traditions of racism, McWhorter underlines how race represents characteristics defined as abnormal within the normalizing society. McWhorter (2009:12) writes,

The white race ... is viewed by most people ... as the normal race, and all other races were and are viewed as deviant with respect to it. Racism plays out, then, as a crusade against deviance, against the threat posed by abnormality or pathology.

In the development of modern Anglo-American racism, McWhorter (2009:34) demonstrates "the fundamental issue is not religion or skin color per se; it is abnormality. Skin colour and religious affiliation are taken as marks of abnormality." Racism from the biopolitical perspective is focussed on forms of behaviour and conduct, similar to how Balibar (1991) traces racialization based on "culture" and behaviour in contem- porary social relations as forms of "racism without race." In the NorthWest, colonial authorities developed a number of criminal offences to outlaw and eliminate practices that marked indigenous practices - such as religious and cultural ceremonies (see Pettipas 1994) — as abnormal and thus culturally inferior. While attentive to abnormal spiritual and cultural practices, colonial authorities reserved even greater suspicion and attention for demarcations of abnormality that came in the form of opposition to settler expansion.

Tracing Foucault's genealogy of racism, Su Rasmussen (2011:40) argues that race and racialization have two distinct facets: as a technology of classification and as a vector for the practice of power. Allowing colonial authorities to classify distinctions between worthy and unworthy life, racial labelling enables either (or both) affirmative and negative interventional technologies to target particular forms of conduct. As an affirmative function to "make live and let die," biopower aims to enculturate and reward modes of conduct that are conducive to the expansion of settler colonialism. Specifically, this means that indigenous peoples are "rewarded" for taking up the lifestyles, economies, and practices of European settlers. This is most clearly demonstrated by early movements to advance agriculturalism, private property, entrepreneurialism, and Christianity (Buckley 1992; Carter 1990). Those individuals who are not successful or compliant, but do not present a significant threat to settler expansionism, will be simply "let die," or supported to maintain only a minimal existence through a work-for-rations system that provides just "enough to keep them alive" (Shewell 2004). However, racialization also provides colonial authorities with a negative function. Subjects or groups who present a significant impediment to the enculturation of settler modes of conduct are further racialized as dangerous Others and regarded as threats to the aggregate population. To sort between worthy and unworthy colonial subjects, race is severed from strictly biological criteria and fixed to forms of conduct and willingness to adapt to the values of white settler society. For persons deemed as threats, sovereign techniques of violence - best defined as forms of necropolitics (Mbembé 2003) or thanatopolitics (Ghanim 2008) - appear completely rationalized, carried out in the name of positing and preserving the law.

While all indigenous people were racialized as Other, those who insisted on treaty provisions and defence of indigenous lands were demarcated as especially deviant and threatening to the aggregate population. Vocal opponents to settler expansionism like Poundmaker and Big Bear were placed under systems of surveillance (Stonechild and Waiser 1997). As a "liberal surveillance complex" (Smith 2009), the colonial gaze seeks out groups or individuals who represent a potential conflict 
- however remote - with settler values. Browne (2012:72) uses the term "racializing surveillance" to underline "those moments when enactments of surveillance reify boundaries and borders along racial lines, and where the outcome is often discriminatory treatment." Racializing surveillance fulfils prefabricated stereotypes and prejudice held by colonial authorities and produces a social hierarchy defined by normative standards and signifiers of whiteness.

While no amount of adaptation to liberal settler society can prevent indigenous peoples from being targeted for structural genocide, biopolitical ordering produces initial categories for the governance and elimination of indigenous populations in the North-West. Mounties in the NorthWest, for example, regularly discriminate between "good Indians" and "bad Indians," whereby individuals are categorized by their adherence to racialized conduct within a settler colonial binary: European/libera (good) and indigenous/traditional (bad). In this context, subject formation overlaps with nation formation. In describing the master narrative of Canadian nationhood, Sunera Thobani (2007:13) shows how European identities (primarily British and French) constituted the " preferred races' within the bureaucratic apparatus of the settler state." As a white European colony, Canadian identity has been formed by the exaltation of settler values, primarily associated with individualized liberal conduct (Thobani 2007). Sorting between good and bad conduct based on racial distinctions between whiteness and Others, racializing surveillance simultaneously confirms notions of indigeneity as abnormal and illiberal, while disaggregating within indigenous populations between worthy and unworthy life; those who can be transformed and those who can be killed. Most importantly, racializing surveillance seeks out any expressions of indigenous practices, sovereignty, or autonomy as immediate threats to the health and security of settler expansionism.

Conceptualizing racialization through nonbiological processes is particularly instructive for examining colonial governance regimes, as studies on colonial governmentality have detailed (Legg 2007; Prakash 1999; Scott 1999). Discussing how rationalities of colonial rule are deployed to manage indigenous populations, Scott (1999) argues that colonial governmentality is defined by a shift from imperial objectives of wealth extraction to focus on permanent governance. As a distinct rationality of power, colonial governmentality "comes to be directed at the destruction and reconstruction of colonial space so as to produce not so much extractive-effects on colonial bodies as governing-effects on colonial conduct" (Scott 1999:40). The formation of colonial administrations arises from the movement from extraction to governance to systematically reorganize the spaces and possibilities of conduct defined by
European norms of racial conduct. Yet, colonial governmentality studies have focussed largely on British practices in contexts where colonial authorities were dramatically outnumbered by indigenous populations; India being the primary example (Legg 2007; Kalpagam 2002; Scott 1999; Prakash 1999). These colonial regimes constructed vast administrative bureaucracies that aimed to monitor, manage, and transform the population into labourers to facilitate industrialization and capital accumulation (Hacking 1982; Cohn 1996). European settlement was not a primary objective.

A key distinction between colonial strategies and settler colonial strategies rests in the settler colonial pursuit of land. As Belich (2009) notes, Anglo-world settler societies were far less interested in extracting surplus labour of indigenous people than they were in possessing indigenous land. In Canada, "capital was far more attracted to the opportunities of native land than to the surplus value of native labour" (Harris 2004:173). Unlike colonial governmentality, settler governmentality aims to dispossess indigenous peoples of their land and, once reduced to minority populations, target them with strict population management systems. Based largely on the reservation system, population management within settler governmentality is a biopolitical strategy that, while balancing discipline and reward, seeks to reform the conduct of indigenous populations according to the model of European normative society. Miller (1989:189-207) has called this the policy of the "bible and the plough." Often negotiated through the creation and imposition of legal authority (Fitzpatrick 1992), settler governmentality treats expressions of traditional indigeneity as forms of abnormality because they represent a barrier to the creation of a new (white) social order. While aiming to neutralize and transform indigenous species-life through interventionist projects, indigenous people who resist the ordering practices of settler society are even further racialized. Not only are they Indians, they are "bad Indians" whose active resistance is seen to threaten the future prosperity of the settler colonial state. In this sense, settler governmentality follows Wolfe's (2006) characterization that a "logic of elimination" rationalizes the process of settler colonialism. Often structured through an "organizing grammar of race" (Wolfe 2006:387), settler governmentality aims to accumulate territory and negate indigenous forms of autonomy or sovereignty through flexible regimes of intervention that combine reformatory projects to transform indigenous species-life, as well as direct violence targeting problematic individuals perceived as immediate threats.

As a rationality of majoritarian rule, settler governmentality seeks to eliminate expressions of autonomy, independence, or collective identity that are at odds with the biopolitical objectives of prosperity through 
liberalism. In an imagined community of white European and liberal values, the existence of indigeneity serves as a challenge and a threat to the normative standards of settler society in two ways: first, it contradicts myths of discovery within the Canadian imaginary (Mawani 2007). Second, it serves as a reminder of illiberal and non-European threats within the nation which underline the need for vigilance in defence of society itself. Settler colonial practices in the North-West territories following Canadian Confederation epitomize both the expansion and elimination logic of settler governmentality.

\section{Surveillance ANd Dangerousness in the Frontier}

Three years after Confederation in 1867, Rupert's Territory was sold by the Hudson's Bay Company (HBC) to the Canadian government. Becoming the North-West Territories in 1870, this vast area encompasses most of current Alberta, Saskatchewan, as well as the Yukon, Nunavut, and Northwest Territories. Prior to the land sale, there were no surveys, land title offices, or paper deeds, and HBC laws rarely expanded outside their outposts (Miller 1989). Not surprisingly the land sale - described by Spry (1983) as the "tragedy of the loss of the Commons" - resulted in a rapid period of transition from common property to a private property regime. Miller (1989:154) has claimed that Canada's land theft was "carried out like a gargantuan real-estate transaction." The land sale was met with indigenous and Métis objections and resistance (Tobias 1983), which led to treaty negotiations - known as the "numbered treaties" or "Morris Treaties" — intended to reconcile questions of land ownership with indigenous peoples (see Miller 2009).

Following the sale of Rupert's Land, Ottawa developed a new interest in establishing a systematic policy of settlement and treaty-making emerged as a central aspect of Prime Minister Macdonald's National Policy (Green 1995). Under the slogan "Canada for Canadians," the National Policy used treaties to clear indigenous peoples from land designated for large-scale settlement. Combined with the 1873 NWMP Act that established a permanent and professional police force throughout the prairies, Macdonald opened "the road to an enormous territorial promise" (Turner 1950). Comparing frontier policing and settlement policies of Canada and Australia, Nettelbeck and Smandych (2010:357) argue that the "subjugation of prairie Indians - like Indigenous people of Australia - was based on the negation of Indigenous sovereignty and the implementation of effective policies of containment and surveillance.' The central element of the surveillance system that was implemented in Western Canada involved the establishment of the reserve system, which was a standard template of Canadian (and British) treaty-making process.
Reserves involved the demarcation of exclusive territories for indigenous groups and provisions for annual annuity payments (Surtees 1969). Smith (2009:9) notes that reserves mirrored institutions identified by Bentham (and Foucault) that might effectively employ disciplinary surveillance as a form of reformatory strategy. Reserves allowed a network of actors - including NWMP officers, Indian agents, religious officials, businessmen, educational workers, etc. - to begin systematically reporting on the activities and conditions of indigenous people on reserves. Information gathered from these sources was compiled and scrutinized by the Department of Indian Affairs (DIA). Gathered in the form of vast tabular statements, information on indigenous people began to far exceed that of the published censuses (Smith 2009). Yet, despite a pervasive system of surveillance targeting indigenous peoples on reserves (or perhaps because of it), settler society increasingly imagined reserves as "dangerous, foreign, and violent places" where whites were not welcome (Furniss 1999:10).

Conditions on reserves in the North-West were very dire during the period following the treaties. Declining buffalo and disease had disastrous consequences for indigenous communities (Pettipas 1994). Fully aware of these conditions, colonial authorities deliberately exploited indigenous suffering to extract more land and further wither indigenous peoples' capacity to oppose the rapid expansion of Canadian settlement (Stonechild and Waiser 1997). Officials regularly exploited the poor position of indigenous people to revoke or deny treaty entitlements. Sarah Carter (1990:78) has detailed how government officials regarded treaty commitments as forms of charity or gratuities, rather than as legally required payments for land that was ceded. These paternalisms were paralleled with an increasing perception of indigenous people as lazy or beggars, widely believed to be deserving of mistrust and fear (Shewell 2004). Persistent associations and stereotypes of indigenous identities served to rationalize additional practices of control, which invariably aimed to further isolate and monitor indigenous populations.

In the context of the North-West, the anxieties of white administrators and settlers were amplified based on racialized stereotypes and fears of nomadic, illiberal, and vengeful outsiders hedged against European civilization. Stoler (2009:106) argues that narratives of the archive are not about "what might have been but what might yet be." Scholars have detailed how anxious and fearful colonial officials often produced voluminous records, imagining different and ominous forms of indigenous danger (Guha 1997). These anxious imaginings involve a "portent-laden future of revolt and betrayal [that] is always on the imminent and dangerous horizon" (Stoler 2009:21) despite the asymmetries of power and the 
violence against indigenous people that accompanied colonial expansion. Fears of organized unrest or irrational violence served to formalize danger-based legitimacy and normalize further mechanisms of surveillance.

To order the North-West under a vision of "normality" that politicians, settlers, and police embraced, settlers concocted oversimplified and prejudiced characterizations of indigenous people that became "selfperpetuating" (Fisher 1977:91). Stereotypes of indigenous people were increasingly infused with generalized characteristics of dangerousness and menace. In colonial contexts this induced calls for regulation as a means to promote, on the one hand, the safety and security of the white population, and, on the other hand, means to surveil levels of adaptation or noncompliance within the indigenous population.

As strategies of colonial rule these are conditioned by long-standing stereotypes of Otherness, as well as particular knowledge of dangers that are produced through surveillance projects on the ground. Within colonial contexts, Bakhle (2010:52) argues that surveillance strategies problematize individuals and groups whose threat is "far more rhetorical and symbolic than physical," because these forms of opposition question "the fundamental legitimacy of colonial rule." As I detail below, the Canadian government actively pursued surveillance programs in the North-West in an effort to determine if "bad Indians" were conspiring to undermine the legitimacy of Canadian authority. The intelligence gathered produced forms of threats and anxieties that combined an abstracted dangerousness of the Other with particularized knowledge of activities from the North-West. Framed through racialized discourses of "good Indians" and "bad Indians" - based on the perceived conduct of those under surveillance - efforts to monitor problematized indigenous leaders in the North-West translated their political opposition through the logic of settler governmentality: as threats to settler normative society.

Bakhle (2010:53) demonstrates that surveillance is the "first weapon" at the disposal of colonial authorities. It is meant to place an increasingly large number of individuals under systematic monitoring. Canadian authorities had limited abilities to practice surveillance on indigenous populations in the North-West; their strategy depended on indigenous people remaining on reserves (Carter 1990). However, beginning in 1884, the DIA developed an active surveillance program that involved infiltration efforts to track indigenous leaders. The infiltration campaign discussed below involved a Métis trader named Peter Ballendine - a loyal (and worthy) subject - who targeted suspected leaders of the panindigenous movement. Ballendine produced knowledge of alliances, networks, populations, dispositions, and capacities of Indian threats, which mixed with settler fears of indigenous dangerousness. While Bal- lendine was only one individual within a very complex social milieu, his surveillance provided the Canadian government with an inside unparalleled intelligence on the pan-indigenous movement. As I will discuss, Ballendine's racialized surveillance reinforced settler governmentalities by calling attention to the leaders of the movement and, unlike racialized subjects (like himself) willing to accept the transformational logic of settler colonialism, his reports contribute to the casting of these individuals as immediate threats to the social order.

\section{Peter Ballendine's Covert Surveillance}

Peter Ballendine was a Métis trader with the HBC and is known to have worked as an interpreter during the Morris treaty negotiations (Stonechild and Waiser 1997:12). It is not clear when Ballendine began working for the DIA, but intelligence reports from his field work began appearing in October, 1884. It seems he was hired until July $1885 .{ }^{1}$ His reports are addressed to Indian Commissioner Edgar Dewdney and Assistant Commissioner Hayter Reed, and it is clear that Ballendine managed to ingratiate himself with his most prominent targets, Big Bear and Poundmaker. Tobias (1983:540) notes that Dewdney believed that his most important staffing move during the Rebellion period was the employment of Ballendine, a fact that cannot be overemphasized when contextualizing these fragmentary correspondence records.

Ballendine's clandestine surveillance was part of mounting tensions in the frontier. Dewdney and the DIA, aware of the growing animosities, were deeply concerned that the pan-indigenous movement could threaten settlement policies. To observe Indians suspected of leading the movement, Ballendine moved constantly, from camp to camp, reporting on the activities of leaders. His logs reveal that he made frequent trips, spanning hundreds of miles throughout the North-West, mostly circulating around Duck Lake, Fort Pitt, Frog Lake, and Carlton. Often Ballendine's reports take a narrative form, going through various individuals and contacts, listing their movements, actions and noting his own plans to continue surveillance activities. They frequently read as follows:

You can arrest $[\mathrm{sic}]$ assured that I will do my utmost to find out the movements as closely as I can. (LAC RG 10, 3582, file 949, Ballendine to Reed, October 10, 1884.)

Beardy messanger [sic] I will follow him up and get to each camp as he leaves so that I can find out all he does and says. (LAC RG 10, 3582, file 949, Ballendine to Regina (Dewdney) November 20, 1884.)

1. Library Archives Canada (LAC) RG10, 3705, file 17, 936, Dewdney to Macdonald, November 27, 1885. 
[Poundmaker] states that the Indians are sending tobacco from camp to camp, and should he hear what is going on he will tell me everything he hears. (LAC RG 10, 3582, file 949, Ballendine to Regina (Dewdney) November 20, 1884.)

Poundmaker stated to me the other day that Little Pine said ... he had made arrangements with the Blackfoot Indians to come here this summer and give us trouble.... Jacob Red Deer stated also that Little Pine said that he reserve $[s i c]$ would be covered with Teapies this Summer. Little Poplar started out yesterday to the Stoney camp. I am going out today to find out what he is doing out there. (LAC RG 10,3705, file 17, 936, Ballendine to Dewdney, January 2, 1885.)

Accounts of Ballendine's activities were sent to Dewdney in Regina, then often forwarded to Ottawa. These materials could never have been accumulated through Ottawa's two primary surveillance resources: NWMP officers and DIA officials (agents and farm instructors). In addition to providing first-hand accounts from leading indigenous figures, Ballendine also gave the Canadian government the opportunity to disrupt indigenous political efforts. In this sense, Ballendine was given the task of surveillance and a mandate to interfere with activities that Ottawa found objectionable. Dewdney explained these activities in a letter to DIA Deputy Superintendent General Lawrence Vankoughnet in Ottawa:

Sir, I have the honour to forward here with $[s i c]$ a copy of a letter received from ... Peter Ballendine whom I consider it was in the interests of the Department to engage in secret service against the Indians of the North, with the view not only of keeping [us] advised of all movement but also of endeavouring to prevent a large gathering in the Spring. (LAC RG 10,3582, file 949, Dewdney to Vankoughnet, December 5, 1884. Emphasis added.)

Ottawa was concerned about the possibility of Big Bear holding a large diplomatic gathering (thirst dance) in the summer of 1885. Ballendine informed officials that at least 12 bands had committed to Big Bear's meeting scheduled for the summer of 1885 at the central location of Chief Beardy's reserve. The DIA feared that this gathering would undo the strategy of isolation that was being implemented through the reserve system and give indigenous communities more political leverage in their negotiations with Ottawa. These expressions of indigenous autonomy were seen as an unacceptable barrier to the advancement of settlement and a rejection of the crown's assertion of sovereignty (Carter 1990). Orders to disrupt these pan-indigenous meetings were given to Ballendine, and he reported on his activities in December 1884:

I know that you could do some good and as you know I will only be glad to assist you all that ... in any power. I visited Big Bear again and will do all I can to prevent him to go down. (LAC RG 10,3582, file 949, Ballendine to Dewdney, December 26, 1884.)
It is unclear what precise actions were taken by Ballendine, aside from sowing confusion through various discussions. Some notes demonstrate that he believed he could persuade indigenous leaders to accep the undesirable terms of Ottawa's making. In a letter from November 20, 1884, Ballendine wrote:

I will stay sometime among Big Bear's People, and will do the best I can to prevent him to join these foolish Indians, and hope I will be able to do with him as I think I have done some good to Poundmaker by talking to him and explaining everything to him for his own good. I think if I mistake not that Poundmaker will again make a good Indian. He promised me in the name of God he will not interfere with any of the other Indians but only his own. If he proves himself to be a good Indian this season I only hope some small inducement be shown him during seed time. (LAC RG 10, 3582, file 949, Ballendine to Regina (Dewdney), November 20,1884.)

Reports from Ballendine, such as the one above, contributed to the Canadian government's long-standing categorization of indigenous people as either "good" or "bad" characters, depending on their willingness to accept the assimilatory and expansionist conditions of settler governmentality. Clearly, as a loyal servant of the Crown, Ballendine embodied the characteristics of a "good Indian" willing to further the settler colonial interests of the Canadian government. For instance on October 10, 1884, he wrote:

Little Pine also states that as far as he knows Big Bear will not take his Reserve and that he is a fort Indian in some respects and a bad one in other respects. (LAC RG 10, 3582, file 949, Ballendine to Reed, October 10, 1884.)

The term "fort Indian" refers to bands or groups of indigenous peoples that are forced to camp near European forts or outposts. The reference to a "fort Indian" underlines the notion that, from the perspective of government, traits of docility and subservience are considered "good," while individuals who refuse to portray an outward display of docility are considered "bad." The categorization of being a "bad Indian" often conveyed an opposition to progress, civilization, or liberalism (Lawrence 2004). While "bad Indians" represented an immediate contagium to be neutralized, uses of division into "good" and "bad" Indians represented only an initial means of enforcing subjugation; ultimately no amount of adaptation to liberal values prevented all indigenous people from being subject to the logic of elimination. ${ }^{2}$ Evidence of indigenous communities

2. I would like to thank an anonymous reviewer for emphasizing this point. I have borrowed their analysis and language - because I could not have made the argumen more clearly. 
taking up liberal, Western practices - only to be stymied by the arbitrary rule of Canadian officials (Carter 1990) - speaks to the racialized hierarchies of settler colonialism. Smith (2012:69) points out that settler colonialism's "logic of genocide" is rooted in the expression of white supremacy where indigenous people "must always be disappearing, in order to enable non-indigenous peoples' right fill claim to land." As settler colonial authorities sought to radically transform the North-West, indigeneity represented a barrier to their visions of prosperity. While all indigenous people would be subject to the genocidal practices of the logic of elimination, Ballendine's correspondence demonstrates Ottawa's fixation on particular indigenous leaders as the locus of threat.

Indigenous leaders were problematized by Dewdney and agents in Ottawa because they were perceived as sources of potential violence. Yet, the pan-indigenous movement was largely focussed on negotiation of treaty promises and land claims. Contrary to accounts from Dewdney and DIA officials, most indigenous communities in the prairies remained loyal to their treaty agreements (Dyke 1986; Stonechild and Waiser 1997), despite Ottawa not fulfilling their obligations. Ballendine frequently reported on the poor conditions faced by these communities and, at times, empathized with their grievances, particularly those groups that he identified as "good Indians." For instance he wrote:

I think myself Poundmaker can be made a good chief ... if he was treated differently. There must be some mistake or some misunderstanding between the parties. I know for my own part ... I can handle Poundmaker as well as my own child and if I am not mistaking you will find him a different man next spring if I can only see him as often as I wish. (LAC RG 10, 3582, file 949, Ballendine to Reed, October 10, 1884.)

Similar references are scattered throughout his letters, which are often complimentary (albeit paternalistically so) of Big Bear and Poundmaker. As both Tobias (1983) and Stonechild and Waiser (1997) detail, the substantive elements of Ballendine's reports confirmed many of the grievances that were at the root of discord in the North-West. However, Dewdney and the DIA were selective in their evaluation of Ballendine's correspondence. While intelligence from Ballendine relayed a nuanced picture of the North-West and consistently reported on the poor conditions endured by indigenous communities, colonial authorities only focussed on, and recirculated elements of, the Ballendine reports that affirmed racialized caricatures of enmity and cast indigenous people as dangers. For example, Battleford Indian Agent Rae wrote to Dewdney on December 27, 1884:

I beg to inform you that Peter Ballendine reports that Big Bear will soon pay a visit here then go on to Duck Lake and Qu'appelle.... It is also reported that owing to Little Pine's visit south a good many Blackfoot intend coming South in Spring to assist the Indians here in their demands and that he Little Pine is very dissatisfied with the way this Band have been treated $[s i c]$ and the old cry that promises have not been fulfilled; this is of course idle ... on his part as he has had everything he asked for in reason and has been especially well treated since his arrival here as his men from the first showed a disposition to work. (LAC RG 10, 3582, file 949, Rae to Dewdney, December 27, 1884.)

Reports of grievances would typically become lost, or deliberately overshadowed, by concerns over the laziness or general noncompliance of indigenous conduct. Rae's reference to Little Pine's "old cry" suggests that no amount of liberal treatment from settler authorities could satisfy indigenous grievances. Making allusions to leaders like Little Pine as illiberal and unreasonable, DIA authorities translated their grievances as an affront to benevolence of settler colonial authorities and a challenge to the fundamental legitimacy of colonial rule. Ballendine's reports of the mounting pan-indigenous opposition caused increasing feelings of alarm and anxiety in Regina and Ottawa, contributing to the rationalization of further punitive and repressive actions from colonial authorities.

Beginning in the early 1880 s, Dewdney began to advocate a policy of "law and order" to crack the determination of uncooperative indigenous leaders. He advocated the assiduous use of criminal laws to control indigenous communities (Hubner 1998). In a letter to Macdonald, Dewdney referred to the policy of criminalization as one of "sheer compulsion" (quoted in Tobias 1983:534). Ballendine clearly echoed these plans and his surveillance reports contributed to Dewdney's resolve in using legal measures to disrupt the pan-indigenous movement. ${ }^{3}$ For example, Ballendine wrote to Dewdney:

3. It is important to note that Ballendine himself was a racialized subject and, within the existing archival records, it is unclear to what extent the DIA trusted Ballendine (despite Ballendine's record of crown loyalty). During one exchange it appears that the DIA had received or sought out intelligence on Ballendine's activities. In a postscript to a letter acknowledging receipt of one of his surveillance reports, Reed writes: "p.s. It would be well, when opportunities occur, to advise with our Agent and let them know anything that may be going on. I hardly think it is advisable that you should call meeting as at
Frog Lake; will not the Indians suspect you are in the employ of the department? You Frog Lake; will not the Indians suspect you are in the employ of the department? You should have conferred with [Indian Agent] Quinn while at [Fort] Pitt" (January 12, 1885). In response, Ballendine writes: "Sir, Yours of 12th instant ... and contents duly noted. I see by your letter that someone [here's] reported to you that I called a meeting at Frog Lake, this I deny. I did once send for Big Bear before I left Frog Lake. I would [feel] much obliged to you if you will give me the name of the person who reported such" (January 31, 1885). In a separate exchange with Dewdney, Ballendine defends his record: "I have been extremely cautious, and that the knowledge must have come to them from some other source. I may also state that I have been particularly careful in my intercourse with Indians" (Ballendine to Dewdney, March 19, 1885). 
Beardy cannot complain he has a pretty fair crop and gets good help. During my visit at his reserve I found every family had a fair supply of food. I would recommend that when the Indian Act comes into force to have some of these leading men put in the lockup to make an example of them. (LAC RG 10, 3582, file 949, Ballendine to Regina (Dewdney), November 20, 1884.)

Dewdney himself advocated the tactic of disposing Indian chiefs using the Indian Act as early as 1883 (Tobias 1983:532). Ballendine contributed to this climate by advocating the arrest of "bad Indians" such as Little Poplar, who refused to work on reserve agriculture projects and continued to move freely in flagrant violation of Ottawa's reserve policy. Following several petitions from Ballendine about Little Poplar, ${ }^{4}$ Ottawa authorized his arrest, describing him as the "worst Indian ... who is capable of advising the Indians to commit any overt act." The arrest order from Vankoughnet was sent to Dewdney, then relayed to Battleford Indian Agent Rae. Through highlighting Little Poplar's ability to advise indigenous people to "commit any overt act," Vankoughnet underlines the contagiousness of indigenous counterconduct. The "any act" is a veiled reference to violence but it conveys Ottawa's concern that indigenous populations are highly vulnerable and cannot be trusted to leave behind their traditional, indigenous cultures and practices.

Despite the order to arrest Little Poplar (and despite the lack of any evidence of criminal wrongdoing), no arrest of Little Poplar took place. Within a month the Rebellion had realigned priorities of the Canadian government. However the materials gathered by Ballendine directly influenced practices of settler governmentality. When Dewdney reports that hiring Ballendine was the most important staffing move during the period, it is precisely because of the intimate details provided by Ballendine's surveillance campaign. He reports on particular conversations, and the particular character of leaders such as Big Bear and Poundmaker. Ballendine offered Ottawa a window into indigenous circles - and the pan-indigenous movement - that was otherwise inaccessible. Yet, Dewdney and the DIA interpreted Ballendine's surveillance only through a settler colonial lens of threat. Ballendine produced racializing surveillance because it reified the divisions between settler Whites and indigenous people, emphasizing the illiberality of indigenous leaders who were perceived as refusing - or resisting — practices of elimination.

In the process of state formation, James Scott (1998:76-77) notes that a colonial functionary "sees" only the activities that are of interest to him, "largely through simplified approximations" of reports and docu-

4. In letters from October 10, November 19, and January 16.

5. LAC RG 10, 3576, file 309 part A,Vankoughnet to Reed, January 27, 1885. ments so that "complex reality must be reduced to schematic categories." By seeing through narrow fields of intelligibility, Scott (1998) underlines how practices of surveillance and categorization are indispensable in the development of direct rule. Scott emphasizes the use of documents like maps and census data, but human intelligence also aids in the construction of categories that glean complexities from their context and simply abstract notions of indigeneity that confirm preexisting stereotypes.

Confirming fixations over indigenous danger and backwardness in the North-West, racializing surveillance produced subjectivities that it claimed only to be describing. In the North-West, colonial authorities mobilized observations from Ballendine to reinforce their concerns that indigenous leaders presented a barrier to the advancement of settler colonialism. Ballendine's surveillance reinforced rigid settler colonial strategies that aimed to break the will of indigenous leaders like Big Bear who maintained strong claims to indigenous autonomy and sovereignty (see Tobias 1983). Ballendine's surveillance was also selectively interpreted through such a narrow field of intelligibility that it fulfilled settler predispositions of indigenous communities that rationalized the surveillance projects to begin with, creating a form of self-referential and selffulfilling feedback effect. These feedback effects began with the identification of indigenous leaders. Even when surveillance on these individuals conveyed they were cooperative, or "good Indians," their movements and activities were problematized as suspect and dangerous. In the detailed reports on Little Poplar, Big Bear, Poundmaker, etc., the problematization of indigenous political leadership through Ballendine's surveillance project produced a number of conflations. When Ballendine's reports were fed back through official networks in Ottawa and Regina, evidence of mounting political opposition - in the form of treaty renegotiations movement - affirmed Ottawa's prior categorization and presumptions about indigenous dangerousness. This feedback effect also transformed generalized fears of dangerousness concocted by stereotypes of racialized Otherness into particularized knowledge of indigenous threat.

The feedback effect of Ballendine's reports contributed to that aggregate perception - or imagination - of dangerousness in the NorthWest. Through insinuations that "bad Indians" would influence and/or infect a broader population, Ottawa's response was to utilize the Rebellion as an excuse to crush "all remaining vestiges of Indian autonomy" (Stonechild and Waiser 1997:192). In the North-West, imputations of dangerousness were informed by knowledge and surveillance on the ground and mixed with the elimination logic of settler governmentality. Veracini (2010:33) notes that "all settler projects are foundationally premised on fantasies of ultimately 'cleansing' the settler body politic of 
its (indigenous and exogenous) alterities." Ballendine's correspondence reveals how the logic of elimination can be expressed through settler colonial actors who view indigeneity as a barrier to the establishment of a new settler society. In particular, Ballendine demonstrates how indigenous leadership was problematized through racializing surveillance as especially illiberal and hostile to settler colonial advancement.

\section{Conclusions}

While a contributing factor, Ballendine's clandestine surveillance reports were not, by any means, exclusively responsible for Ottawa's militaristic reaction to the North-West Rebellion. Tensions had been escalating since the early period of post- 1870 settlement in the North-West and the Rebellion resulted from these dynamic tensions (Tobias 1983). However, Ballendine's aspersions were used to criminalize Big Bear and Poundmaker, which led to their imprisonment (and deaths) and the complete neutralization of the pan-indigenous movement (Bingaman 1975). Moreover, Ottawa used the threats of "bad Indians" to enact highly repressive systems of control over the North-West. Most dramatically this included the apartheid-like pass system (Jennings 1986), a complete ban on religious and cultural expressions (Pettipas 1994), and residential/industrial schools that intended to "kill the Indian and save the child" (Miller 1989:125-147). Overarching all matters of "Indian affairs" was the Indian Act, which aimed at "civilizing the Indians" and has been used coercively to govern almost every aspect of Indian life, including the legal and cultural subjectivities of indigenous people (see Lawrence 2004).

Following the Rebellion, Dewdney was instructed to "quietly collect evidence" against all Indians suspected of any wrongdoing, no matter how trivial (Stonechild and Waiser 1997:196). In the trials following the Rebellion, Indians were sentenced for various offences, more than twice the number of Métis convictions, that culminated in the largest public execution in Canadian history: eight indigenous men convicted without legal representation by an all-white jury (see Beal and Wright 2009). As Stonechild and Waiser (1997:215) argue, the trials and executions were designed to kill the momentum for reopening treaty negotiations. The broader political motives were expressed in a letter by Prime Minister Macdonald to Dewdney, one week before the hangings: "the executions ... ought to convince the Red Man that the White Man governs" (quoted in Waiser 2009).

Macdonald's rationalization of public executions clearly falls within Foucault's (or Mbembé's) articulation of sovereign power. Acts of sovereign violence as well as "softer" strategies of "structural genocide"
(Wolfe 2006:401) cannot be separated from the racialized sorting and the normative values of white supremacy that inform settler colonial relations. Informing strategies that are inherently eliminating, settler governmentality imagines indigeneity as an illiberal threat to the health and prosperity of settler society. Peter Ballendine's surveillance practices served to identify and amplify markers of indigeneity, and contributed to the repressive policies of the Canadian government by providing particularized knowledge of indigenous movements. As selectively interpreted knowledge, Ballendine's racializing surveillance naturalized the theft of indigenous land and underlined the feelings of urgency towards removing indigenous impediments to the adoption of settler values and conduct. Wolfe (2006:388) notes, "the primary motive for elimination is not race (or religion, ethnicity, grade of civilization, etc.) but access to territory." In the North-West, the pan-indigenous movement was the primary impediment to settler expansion, thereby necessitating its immediate elimination.

Unlike colonial governmentality that focuses primarily on population management, settler governmentality is focused primarily on the acquisition of territory. Race becomes a signifier of threat when racialized individuals do not adopt and recirculate the rewards system offered by the settler colonial state. Defiled as savage, deviant, abnormal, and backwards, expressions of indigeneity were systematically repressed by Canadian authorities as they developed reformatory strategies focussed on making Indians into proper Canadians (see Lawrence 2004). Documents from Ballendine illustrate how racializing surveillance functions according to the logic of settler governmentality by tying subject formation with nation formation. As perceptions of racialized conduct serve as a reminder of illiberal and non-European dangers within the nation, settler colonial actors interpret a host of grievances and activities as threats that reify the racialized distinctions between settler society and indigenous peoples. This underlines the need for vigilance against dangers in defence of society itself and illustrates how settler colonial practices in the North-West territories following Canadian Confederation epitomize both the expansion and elimination logic of settler governmentality.

\section{REFERENCES}

Bakhle, Janaki. 2010. Savarkar (1883-1966), sedition and surveillance: The rule of law in a colonial situation. Social History 35(1):51-75.

Balibar, Etienne. 1991. Is there neo-racism? Pp. 17-28 in E. Balibar and I. Wallerstein, eds., Race, Nation, Class: Ambiguous Identities. London: Verso. 
Beal, Bob and Barry Wright. 2009. Summary and incompetent justice: Legal responses to the 1885 crisis. Pp. $353-410$ in B. Wright and S. Binnie, eds., Canadian State Trials Volume III, 1840-1914. Toronto: University of Toronto Press.

Belich, James. 2009. Replenishing the Earth: The Settler Revolution and the Rise of the Anglo-world, 1783-1939. Oxford: Oxford University Press.

Bingaman, Sandra. 1975. The trials of Poundmaker and Big Bear, 1885. Saskatchewan History 28(3):81-102.

Browne, Simone. 2012. Race and surveillance. Pp. $72-79$ in K. Ball, K. Haggerty, and D. Lyon, eds., Handbook on Surveillance Studies. New York: Routledge.

Buckley, Helen. 1992. From Wooden Ploughs to Welfare. Montreal: McGillQueens University Press.

Carter, Sarah. 1990. Lost Harvests: Prairie Indian Reserve Farmers and Government Policy. Montreal: McGill-Queen's University Press.

Crosby, Andrew and Jeffrey Monaghan. 2012. Settler governmentality and the Algonquin of Barriere Lake. Security Dialogue 43(5):420-437.

Cohn, Bernard. 1996. Colonialism and its Forms of Knowledge. Princeton, NJ: Princeton University Press.

Dyke, Noel. 1986. An opportunity lost: The initiative of the Reserve Agricultura Programme in the prairie west. Pp. 121-138 in L. Barron and J. Waldram, eds., 1885 and After: Native Society in Transition. Regina: Canadian Plains Research Centre, University of Regina.

Fisher, Robin. 1977. Contact and Conflict: Indian-European Relations in British Columbia, 1774-1890. Vancouver: University of British Columbia Press.

Fitzpatrick, Peter. 1992. The Mythology of Modern Law. New York: Routledge.

Francis, Daniel. 1992. The Imaginary Indian: The Image of the Indian in Canadian Culture. Vancouver: Arsenal Pulp Press.

Furniss, Elizabeth. 1999. The Burden of History: Colonialism and the Frontier Myth in a Rural Canadian Community. Vancouver: University of British Columbia Press.

Ghanim, Honaida. 2008. Thanatopolitics: The case of the colonial occupation in Palestine. Pp. 65-81 in R. Lentin, ed., Thinking Palestine. London: Zed Books

Green, Joyce. 1995. Towards a detente with history: Confronting Canada's colonial legacy. International Journal of Canadian Studies 12:85-105.

Guha, Ranajit. 1997. Not at home in empire. Critical Inquiry 23(3):482-493.

Hacking, Ian. 1982. Biopower and the avalanche of numbers. Humanities in Society 5:279-295.

Harris, Cole. 2004. How did colonialism dispossess? Comments from an edge of empire. Annals of the Association of American Geographers 94(1):165182.
Hubner, Brian. 1998. Horse stealing and the borderline: The NWMP and the control of Indian movement, 1874-1900. Pp. 53-70 in W.M. Baker, ed., The Mounted Police and Prairie Society, 1873-1919. Regina: University of Regina, Canadian Plains Research Centre.

Jennings, John. 1986. The North West Mounted Police and Indian policy after the 1885 Rebellion. Pp. 225-240 in L. Barron and J. Waldram, eds., 1885 and After: Native Society in Transition. Regina: Canadian Plains Research Centre, University of Regina.

Kalpagam, Uma. 2002. Colonial governmentality and the public sphere in India. Journal of Historical Sociology 15(1):35-58.

Kelly, Mark. 2004. Racism, nationalism and biopolitics: Foucault's society must be defended, 2003. Contretemps 4, September.

Lawrence, Bonita. 2004. 'Real' Indians and Others. Lincoln: University of Nebraska Press.

Legg, Stephen. 2007. Spaces of Colonialism: Delhi's Urban Governmentalities. Malden, MA: Blackwell Publishers.

Mawani, Renisa. 2007. Legalities of nature: Law, empire, and wilderness landscapes in Canada. Social Identities 13(6):715-734.

2009. Colonial Proximities: Crossracial Encounters and Juridical Truths in British Columbia, 1871-1921. Vancouver: University of British Columbia Press.

Mbembé, Achille. 2003. Necropolitics. Public Culture 15(1):11-40.

McWhorter, Ladelle. 2009. Racism and Sexual Oppression in Anglo-America: A Genealogy. Bloomington: Indiana University Press.

Miller, J.R. 1989. Skyscrapers Hide the Heavens: A History of Indian-White Relations in Canada. Toronto: University of Toronto Press.

2009. Compact, Contract, Covenant: Aboriginal Treaty-Making in Can ada. Toronto: University of Toronto Press.

Nettelbeck, Amanda and Russell Smandych. 2010. Policing indigenous peoples on two colonial frontiers: Australia's Mounted Police and Canada's North-West Mounted Police. The Australian and New Zealand Journal of Criminology 43(2):356-375.

Pettipas, Katherine. 1994. Severing the Ties that Bind. Winnipeg: University of Manitoba Press.

Prakash, Gyan. 1999. Another Reason: Science and the Imagination of Modern India. Princeton, NJ: Princeton University Press.

Scott, David. 1999. Refashioning Futures: Criticism after Postcoloniality. Princeton, NJ: Princeton University Press.

Scott, James. 1998. Seeing Like a State. New Haven, CT: Yale University Press.

Shewell, Hugh. 2004. 'Enough to Keep Them Alive': Indian Welfare in Canada, 1873-1965. Toronto: University of Toronto Press. 
Smith, Richard. 1985. Rule-by-records and rule-by-reports: Complementary aspects of the British imperial rule of law. Contributions to Indian Sociology 19(1):153-176.

Smith, Keith. 2009. Liberalism, Surveillance, and Resistance: Indigenous Communities in Western Canada, 1877-1927. Edmonton: University of Alberta Press.

Spry, Irene. 1983. The tragedy of the loss of the commons in Western Canada. Pp. 203-228 in I. Getty and A. Lussier, eds., As Long as the Sun Shines and Water Flows: A Reader in Canadian Native Studies. Vancouver: University of British Columbia Press.

Stoler, Ann Laura. 1995. Race and the Education of Desire. Durham, NC: Duke University Press. 2009. Along the Archival Grain: Epistemic Anxieties and Colonial Common Sense. Princeton, NJ: Princeton University Press.

Stonechild, Blair and Bill Waiser. 1997. Loyal Till Death: Indians and the NorthWest Rebellion. Calgary, AB: Fifth House.

Su Rasmussen, Kim. 2011. Foucault's genealogy of racism. Theory, Culture and Society 28(5):34-51.

Surtees, Robert. 1969. The development of an Indian reserve policy in Canada. Ontario History 61:87-98.

Thobani, Sunera. 2007. Exalted Subjects. Toronto: University of Toronto Press.

Tobias, John. 1983. Canada's subjugation of the Plains Cree, 1879-1885. Canadian Historical Review 64(4):519-48.

Turner, John Peter. 1950. North-West Mounted Police; 1873-1893. Ottawa: King's Printer.

Veracini, Lorenzo. 2010. Settler Colonialism: A Theoretical Overview. New York: MacMillan Palgrave.

Waiser, Bill. 2009. The white man governs: The 1885 Indian trials. In B. Wright and S. Binnie, eds., Canadian State Trials Volume III: Political Trials and Security Measures, 1840-1914. Toronto: University of Toronto Press.

Wolfe, Patrick. 2006. Settler colonialism and the elimination of the Native. Journal of Genocide Research 8(4):387-409.

Jeffrey Monaghan is a PhD Candidate in the Department of Sociology at Queen's University, and a student member of the Surveillance Studies Centre. His MA research focussed on NWMP policing strategies in the North-West during the mid-1880s. 